\title{
Interactions between prostaglandins, leukotrienes and HIV-1: Possible implications for the central nervous system
}

\author{
Jonathan Bertin ${ }^{1}$, Corinne Barat ${ }^{1}$, Sylvie Méthot ${ }^{1}$ and Michel J Tremblay ${ }^{1,2^{*}}$
}

\begin{abstract}
In HIV-1-infected individuals, there is often discordance between viremia in peripheral blood and viral load found in the central nervous system (CNS). Although the viral burden is often lower in the CNS compartment than in the plasma, neuroinflammation is present in most infected individuals, albeit attenuated by the current combined antiretroviral therapy. The HIV-1-associated neurological complications are thought to result not only from direct viral replication, but also from the subsequent neuroinflammatory processes. The eicosanoids - prostanoids and leukotrienes - are known as potent inflammatory lipid mediators. They are often present in neuroinflammatory diseases, notably HIV-1 infection. Their exact modulatory role in HIV-1 infection is, however, still poorly understood, especially in the CNS compartment. Nonetheless, a handful of studies have provided evidence as to how these lipid mediators can modulate HIV-1 infection. This review summarizes findings indicating how eicosanoids may influence the progression of neuroAIDS.
\end{abstract}

Keywords: HIV-1, Eicosanoids, Prostaglandins, Leukotrienes, NS-398, COX-2, 5-LO, Central Nervous System

\section{Background}

HIV-1, which will be referred to as HIV throughout this review, is widely known to cause devastating effects on the immune system. Another important target is the central nervous system (CNS), where macrophages and microglial cells are the cell types predominantly infected by HIV and responsible for virus propagation within the CNS. The effect of various molecules that act as activators or suppressors in the modulation of HIV replication dictates the viral load in the CNS. Although several such molecules have been shown to be involved in the neuropathogenesis of HIV infection and in the development of HIV-associated dementia (HAD), the relative importance of several others remains elusive. Of these, eicosanoids - more precisely prostaglandins (PGs) and leukotrienes (LTs) - have gained some attention during recent years for their implication in HIV pathogenesis. It is well documented that these lipid mediators perform multiple functions in many biological systems, mainly in

\footnotetext{
* Correspondence: michel.j.tremblay@crchul.ulaval.ca

${ }^{1}$ Centre de Recherche en Infectiologie, Centre Hospitalier Universitaire de

Québec - CHUL, 2705 boul. Laurier, Québec (QC), Canada, G1V 4G2

Full list of author information is available at the end of the article
}

inflammation and immunity. In the CNS, they play important physiological roles, notably in the resolution of inflammation and neuroprotective bioactivity. However, little is yet known on the complex relationships between HIV and these soluble mediators in the CNS. The current review will thus focus on the putative contribution of eicosanoid derivatives, namely PGs and LTs, to viral load and HIV-mediated neurological complications.

\section{HIV and the CNS NeuroAIDS}

It is now well accepted that HIV can cross the bloodbrain barrier (BBB) and infect the CNS early, during the acute phase of the infection [1]. In the late stages of the infection, a wide range of neuropathologic complications are observed, such as neurotoxicity, neurodegeneration, HIV encephalitis and associated neurocognitive deficits. Neurological disorders are still strikingly prevalent, reaching up to $50 \%$ of virus-infected individuals during the course of the disease [2]. Clinical manifestations consist in a triad of neurological symptoms including cognitive, motor and behavioural impairments, better
C Biomed Central

(C) 2012 Bertin et al; licensee BioMed Central Ltd. This is an Open Access article distributed under the terms of the Creative Commons Attribution License (http://creativecommons.org/licenses/by/2.0), which permits unrestricted use, distribution, and reproduction in any medium, provided the original work is properly cited. 
known as HAD. Before the introduction of the highly active antiviral therapy (HAART) in 1995, most of the infected population developed HAD at the late stage of the disease. HAART has reduced this rate drastically. However, a more subtle form of CNS dysfunction, known as minor cognitive motor disorder (MCMD) continues to prevail in HIV-carrying persons. Symptoms of MCMD include memory loss, as well as reduction of cognitive and computational functions [3]. Thus, the neurological manifestations and the inflammatory cascade underlying the infection of the CNS by HIV are far from being controlled by HAART. In fact, the relative CNS penetration-effectiveness (CPE) scores for different antiretroviral drugs used in HAART vary considerably, from very poor (e.g. enfuvirtide and nelfinavir) to high penetration (e.g. nevirapine and zidovudine) [4,5]. Nevertheless, it has been shown that the clinical outcome of CNS impairments related to HIV infection does not depend on the penetration efficacy of administered antiretroviral drugs [4]. In some cases, HIV-associated neurological disorders are actually worsened by the use of antiretrovirals [6]. A recent study has notably shown that maraviroc, a widely used CCR5 antagonist, actually increases microglia proinflammatory activation by inducing PGs synthesis, which may have the potential to exacerbate neurological complications [7].

Discordance between plasma and CSF (cerebrospinal fluid) viral loads in HIV-infected individuals has been documented in the literature [8-10]. Interestingly, HAART treatment seems to reduce the viral RNA concentrations more slowly in the CSF of some patients than in their plasma [11]. As a corollary, some studies have also shown that progression of HIV titers in the CNS occurs more slowly than in the plasma of patients with no neurological symptoms associated to HIV infection $[12,13]$. How the human body can control the viral load in the CNS is still not fully understood. Moreover, CNS viral strains may genetically differ over time from those found in the peripheral blood [14]. In the light of these observations, an involvement of cerebral innate immunity is probable. Indeed, it has been shown in non-human primate models that simian immunodeficiency virus (SIV) replication is more efficiently controlled in the CNS compartment than in the plasma [15]. In these models, the innate immune response seems to act as a key regulator of the viral burden in the CNS [16].

\section{Entry in and infection of the CNS by HIV}

A wealth of knowledge has been published on the Trojan horse model describing how the virus may enter the CNS via infected leukocytes (mostly monocytes and/or $\mathrm{CD}^{+} \mathrm{T}$ lymphocytes) or via cell-independent pathways [17-21]. This process is facilitated by a BBB disruption brought about by circulating microbial endotoxins such as lipopolysaccharide found on Gram-negative bacteria - that enter the blood stream by translocation from the gastrointestinal tract during the acute phase of HIV infection [22-24] and by soluble HIV proteins such as Tat, Nef and gp120 [25]. HIV is then considered to be compartmentalized, on the one hand in the peripheral immune system, and, on the other hand, in the CNS. Once the virus enters the latter compartment, perivascular macrophages and microglia are the main targets for productive HIV infection. These cells can notably act as stable reservoirs for HIV latency (reviewed in [26]). Moreover, the infection and activation of these cells leading to production of proinflammatory mediators in the CNS underlie the pathogenesis of neuroAIDS [27]. Indeed, these inflammatory molecules do not only impact the function of surrounding cells, but can also alter tight junctions of the $\mathrm{BBB}$, and enhance monocyte recruitment [28]. Among these secreted factors are eicosanoids, the focus of this paper.

\section{Microglia and HIV}

Microglial cells are tissue macrophages that are ubiquitously distributed in the CNS. They serve as neuroprotective cells and promote neurotrophic functions [29]. It is now believed that microglia colonize the CNS from two pools of myeloid cells. The first progenitors that enter the embryonic and foetal CNS derive from hematopoietic cell precursors [30,31]. The second wave consists in monocytes, predominantly expressing some specific surface markers (i.e. CD11, CD14 and CD16), that enter and colonize the CNS during the postnatal period (infiltrating microglia) [32-34]. Microglial cells play many important roles in homeostasis. They can act as antigen-presenting cells, remove tissue debris following a brain trauma, cross-talk with astrocytes in order to regulate their proliferation, and produce cytokines and chemokines, as well as other soluble factors known to be involved in immunologic response, neuroinflammation and neurodegeneration [35-39].

As mentioned above, HIV once located within the CNS will predominantly target microglial cells and perivascular macrophages for productive infection. The virus-encoded external envelope glycoprotein gp120 utilizes different chemokine receptors and adhesion molecules in combination with CD4 to establish an initial contact with targets and eventually gains entry inside a host cell. It is well documented that microglia are mostly permissive to R5-tropic strains of HIV, which enter via the CCR5 coreceptor [40-42]. However, some data suggest that certain strains of HIV can also partly utilize CCR3, therefore suggesting some degree of complexity in the coreceptor usage by the virus on the surface of microglia $[42,43]$. 
HIV and certain virus-induced soluble factors have been shown to activate microglial cells. Interestingly, there is a better correlation between HAD and microglial activation than with the viral load [44]. The gp120 envelope protein is one of many viral components released in infected tissues. It has been shown to colocalize with microglia in the brain of HIV-infected patients [45]. Exposure of microglia to gp120 has been reported to induce an activation response, including the release of several molecules - such as TNF- $\alpha$, IL-6, IL-1 $\beta$, GMCSF and reactive oxygen species - that induce CNS inflammation and neurotoxicity $[19,46,47]$. Another HIV protein, namely Tat, can also be found in the CSF and brain of HIV-infected individuals [48]. Treatment of human microglial cells with exogenous Tat can trigger the secretion of a broad range of proinflammatory molecules (e.g. MCP-1, IL-8, MIP-1 $\alpha$, MIP-1 $\beta$ and RANTES) [19].

Experiments aimed at defining the complex interactions between HIV and human microglia have used purified primary microglial cells obtained from human foetal brain tissues or brain specimens of patients undergoing surgery. However, the limited quantity of microglia that can be thus obtained has been a limiting step. Interestingly, a novel model of primary human microglia called human monocyte-derived microglia-like cells (MDMi) has been developed [49]. The phenotype of these cells resembles that of primary infiltrating microglia found in the CNS, and they can support productive HIV infection. This experimental model of human microglia has been recently proven to be useful for studying in vitro HIV infection in the CNS context [50]. Alternatively, animal models using SIV have been developed, which may prove useful for correlating the in vitro studies with an in vivo approach [51].

\section{Astrocytes and HIV}

Astrocytes are the most abundant glial cells in the CNS. They play several important roles, such as regulating the external environment of neurons, participating in the physical structuring of the brain, providing metabolites to neurons, and maintaining the BBB integrity. Although perivascular macrophages and microglia are the cells that support productive virus infection in the CNS, astrocytes are considered by many to support a restricted virus replication. Indeed, only a subpopulation of productively infected astrocytes can be detected in vivo in $\mathrm{HAD}$ patients by sensitive techniques that detect virus nucleic acids [52-55], although an extensive infection of these cells has also been reported in demented infected individuals [56]. Nonetheless, much interest has lately been focused on the infectability of astrocytes. Their limited susceptibility to productive HIV infection has been attributed to a $\mathrm{pH}$-independent restriction at the virus entry step $[53,54]$ and an inhibition of the Rev protein by a host restriction factor called Risp [57].

Latent HIV infection of astrocytes results in considerable changes in the host gene expression pattern $[58,59]$. Consequently, the secretome of infected astrocytes has a major impact on neuronal cell death and BBB dysregulation, and it correlates with HIV neuropathogenesis and HAD severity [20,52]. Furthermore, recent findings suggest that the infection of a small number of astrocytes is sufficient to disrupt the BBB integrity by a gap junctiondependent mechanism [60], thus reinforcing the proposed important role for these few infected astrocytes in the HIV-induced CNS damage.

Interestingly, cross-talk between HIV-infected astrocytes and microglia has important impacts on neuroinflammation and neurodegeneration processes seen in the CNS. Indeed, HIV infection of astrocytes can increase the neurotoxicity of infected microglia and modulate viral growth and compensatory regulatory pathways in these cells [61]. Therefore, the very low number of virus-infected astrocytes can still play an important role in the development of HIV-associated encephalitis and neurological impairments.

\section{Eicosanoids}

Eicosanoids are signalling molecules that are generated through an oxidative pathway from polyunsaturated fatty acids, notably arachidonic acid (AA), an n-6 fatty acid (or omega-6), and eicosapentaenoic/docosahexaenoic, an n-3 fatty acid. The eicosanoids are considered as local hormones that include prostanoids (i.e. PGs, prostacyclins and thromboxanes), LTs, lipoxins, hepoxilins and hydroxyeicosatetraenoic (HETE) acid. They are important homeostatic or proinflammatory lipid mediators that exert autocrine and paracrine activities in diverse physiologic responses (e.g. vasomodulation, platelet aggregation and bronchodilatation). Of more relevance here, PGs and LTs strongly regulate our innate and humoral immunity responses. Production of several eicosanoids is considerably increased during inflammation, and they are involved in the pathogenesis of various diseases.

\section{Biosynthesis pathway from AA}

Once cells are exposed to different physiological or pathological stimuli such as cytokines, growth factors or physical trauma, AA is cleaved from membrane phospholipids by the action of the enzyme phospholipase $A_{2}$ $\left(\mathrm{PLA}_{2}\right)$ (Figure 1). From then on, the free fatty acid may undergo transformation either through the cyclooxygenase (COX) pathway, giving rise to PGs, or through the lipoxygenase pathway, notably producing LTs. In the latter case, AA is transferred by the five-lipoxygenase activating protein (FLAP) to 5-lipoxygenase (5-LO), an 
In nuclear, Golgi and ER membrane

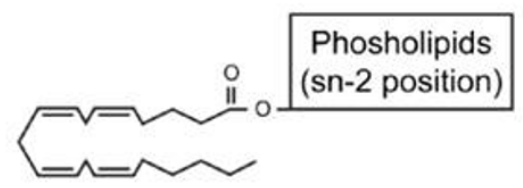

\section{Arachidonic acid}

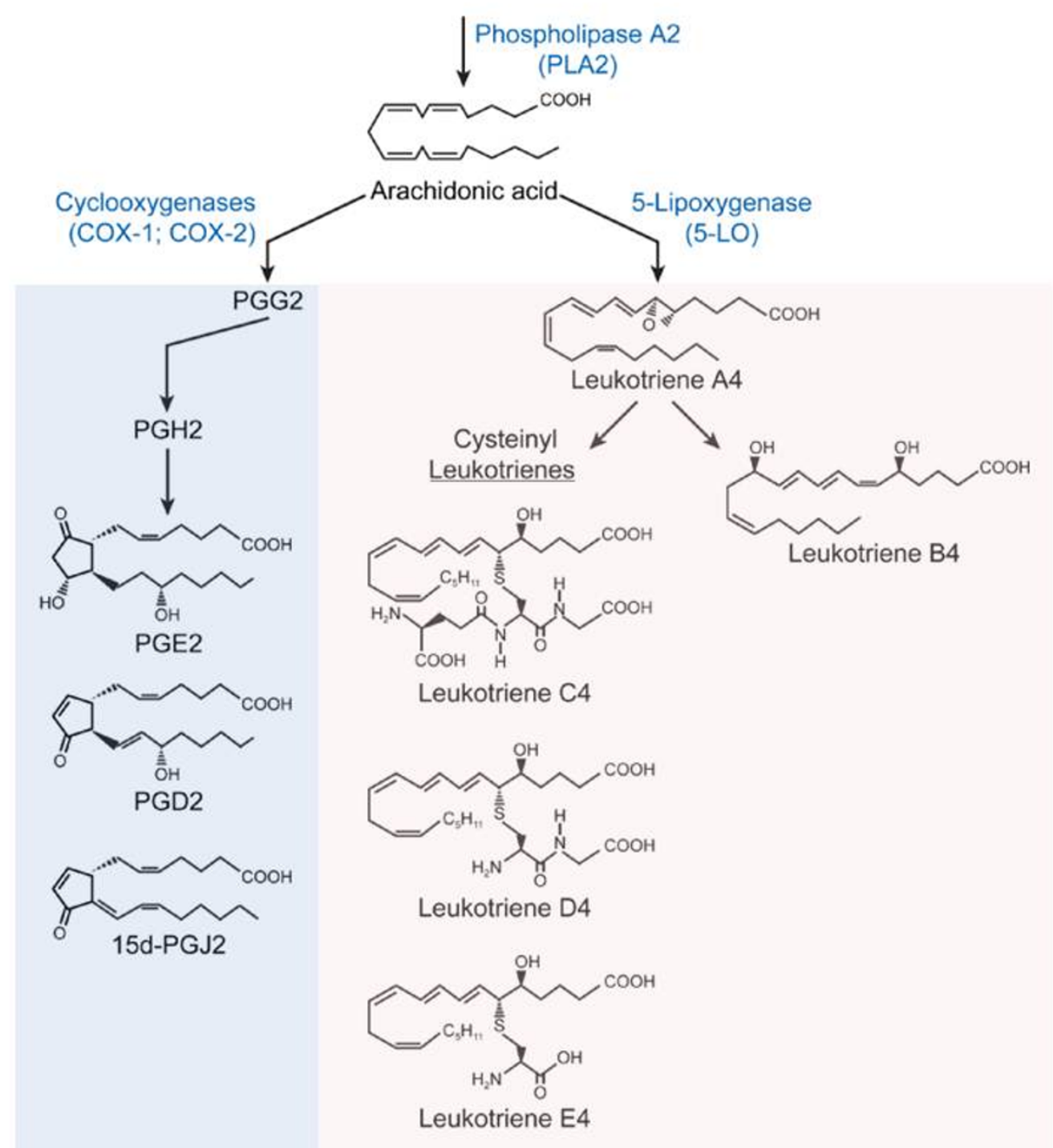

Prostaglandins

Leukotrienes

Figure 1 Metabolic pathway of AA transformation into eicosanoid products. Once a cell is activated by a proinflammatory stimulus that engages a Gaq-coupled seven-transmembrane receptor, AA can be cleaved by cytosolic PLA from phospholipids that compose cellular membranes (mostly nuclear, endoplasmic reticulum or Golgi membranes)[173]. Free AA can subsequently be converted into different eicosanoid products by different enzymes (represented in blue), notably the COX and LO pathways. This review will mainly focus on the prostanoids - PGE 2 , and $15 \mathrm{~d}-\mathrm{PG} \mathrm{J}_{2}$ prostaglandins - and on 5-LO products, namely LTs. Only eicosanoids and pathways of interest in this paper are depicted. 
enzyme primarily expressed in most leukocytes [62]. Thereafter, 5-LO converts AA into $\mathrm{LTA}_{4}$ [63]. This unstable intermediate can then be metabolized into $\mathrm{LTB}_{4}$ by $\mathrm{LTA}_{4}$ hydrolase or into $\mathrm{LTC}_{4}$ by $\mathrm{LTC}_{4}$ synthase [64]. On the other hand, PGs are produced by most nucleated cells in our body, and formed by the rate-limiting COXs. COX-1 is generally thought to be a constitutively expressed enzyme, while COX-2 is highly inducible under inflammatory conditions through the control of the ubiquitous mammalian transcription factor NF-kB $[65,66]$. COX-2 is especially important in cells that are involved in inflammation, such as macrophages and monocytes, and is responsible for the synthesis of those prostanoids involved in severe inflammatory states. It is noteworthy that, in the brain, an alternatively spliced COX-1 isoform, termed COX-3, might also be in play $[67,68]$. COX enzymes produce $\mathrm{PGH}_{2}$, which is then converted into several isomers via various cell-specific synthases, as reviewed by [69].

\section{Biological functions}

It has been well documented that PGs are important homeostatic or proinflammatory lipid mediators which act in an autocrine and paracrine manner. They are implicated in a wide array of biological functions such as vasoconstriction, vasodilatation, aggregation, chemotaxis, fever, pain response and asthma [70]. This family of potent hormone-like substances include $\mathrm{PGE}_{2}, \mathrm{PGD}_{2}$, and $\mathrm{PGF}_{2 \alpha}$. As for $\mathrm{PGD}_{2}$, it can subsequently be converted into the J class of PGs, which include the cyclopentenone $15 \mathrm{~d}-\mathrm{PGJ}_{2}$ [71-73]. $\mathrm{PGE}_{2}$ is a well-known inflammatory modulator implicated in diverse physiological conditions such as vasodilatation, pain, fever, relaxing of smooth muscles, neuronal function and inhibition of noradrenalin release from sympathetic nerve terminals. As for $15 \mathrm{~d}-\mathrm{PGJ} \mathrm{J}_{2}$, this PG is produced in mast cells, platelets and alveolar macrophages. It has been documented as a potent inflammatory regulator, given its capacity to inhibit cytokine secretion and functions of both antigenpresenting cells and T lymphocytes [74,75].

LTs are potent proinflammatory mediators, which are involved in many innate immunological processes such as leukocyte adhesion, chemotaxis and activation $[70,76]$. They regulate the immune response to different stimuli, and are known to play an important role in asthma, vascular disease, cancer and other pathological conditions [77]. Produced in leukocytes, LTs include $\mathrm{LTB}_{4}$ and several cysteinyl leukotrienes (cysLTs) (e.g. LTC4, LTD4 and LTE4) (Figure 1). $\mathrm{LTB}_{4}$ is known as a potent chemoattractant, also capable of inducing the formation of reactive oxygen species and the release of lysosome enzymes by most leukocytes. Known as the slow-reacting substances of anaphylaxis, cysLTs induce inflammation, and may also, when in excess, induce anaphylactic shock. Macrophages produce both $\mathrm{LTB}_{4}$ and CysLTs. As part of the innate immune response, antimicrobial effector functions modulated by LTs include direct effects, such as promotion of leukocyte accumulation and enhancement of macrophages and neutrophils microbe phagocytosis and killing capacity, as well as indirect effects, via the production of other inflammatory molecules [78].

The recently-discovered eoxins are closely related to cysLTs, and are also proinflammatory, but are produced via the 12/15-LO pathways. For instance, 15-HETE is produced from AA in most immune cells which carry 15-LO, such as neutrophils [79], endothelial cells [80], and macrophages [81]. This lipid mediator is mainly produced during inflammatory and immunological conditions, and is known to modulate inflammatory diseases by influencing different biological responses such as chemotaxis, hormone secretion, ion transport and various enzymatic pathways in a receptor-specific manner. Although its extracellular receptor remains to be identified, 15-HETE is known to serve as an endogenous ligand for the peroxisome proliferators activated receptors $[82,83]$.

\section{LT and PG receptors}

Eicosanoids mostly exert their effects by binding to seven transmembrane-spanning receptors, more specifically Gq- and Gi-protein coupled receptors (GPCR), found on most leukocytes. Engagement of an LT receptor is generally associated with a decrease of cyclic adenosine monophosphate (cAMP) and an increase in intracellular calcium followed by an activation of phosphatidyl inositol 3-kinase, protein kinase C, MAP kinase, Rac and NF-kB [84-87]. The receptors for $\mathrm{LTB}_{4}$ are known as $\mathrm{LTB}_{4}$ receptor $1\left(\mathrm{LTB}_{4}\right.$ receptor, or BLT1) - a high affinity receptor, and BLT2 - a low affinity receptor. BLT1 is preferentially expressed on leukocytes, while BLT2 is ubiquitously expressed. CysLTs engage cysLT1, cysLT2 or GPR17 receptors $[77,88,89]$, although the latter may regulate the signalling from cysLT1 in response to cysLTs [90].

Regarding PGs, they act on a broader range of receptors. $\mathrm{PGE}_{2}$, for example, will engage E-prostanoid receptors EP1, EP2, EP3 or EP4, which each has distinct biochemical properties and tissue and cellular localization, which explains the very disparate effects of this PG, depending on the cell type [91]. As for $15 \mathrm{~d}-\mathrm{PGJ}{ }_{2}$, no specific receptor has been identified to date. Instead, it has been shown to act via $\mathrm{PGD}_{2}$ receptors (DP1 and DP2) and through interaction with intracellular targets, including nuclear receptors and non-receptor proteins [92]. In particular, $15 \mathrm{~d}-\mathrm{PGJ}_{2}$ is recognized as the endogenous ligand for the intranuclear receptor peroxisome proliferator-activated receptor- $\gamma($ PPAR- $\gamma$ ) [74]. 


\section{Known interactions between eicosanoids and HIV, outside the CNS PGs and HIV}

The anti-HIV properties of PGs are well documented [93-96]. However, only a handful of studies have attempted to elucidate the mechanisms involved. For example, it has been clearly shown that $\mathrm{PGE}_{2}$ induces resistance of monocyte-derived macrophages (MDMs) to HIV infection by negatively modulating the surface expression of CCR5 - the main coreceptor used by R5tropic strains to enter host cells in a $\mathrm{pH}$-independent manner. It does so through augmentation of cAMP cellular concentration [97] which, in turn, activates a protein kinase A (PKA)-dependent mechanism [98]. One may speculate that activation of PKA through a cAMP increase may regulate CCR5 levels by heterologous desensitization (whereby the activation of a GPCR by its agonist causes downregulation of another GPCR on the same cell). In correlation to these findings, a recent study has shown that over-expression of PG synthase-2 greatly reduces the levels of HIV replication in primary human monocuclear cells [99]. These observations are, however, in contrast to a study by Dumais and colleagues showing that $\mathrm{PGE}_{2}$ can facilitate HIV production in a $\mathrm{T}$ cell line by inducing transcriptional activation of the virus regulatory elements (i.e. long terminal repeat/ LTR) [100]. This discrepancy could be explained by the different cell types used in the two studies and the nature of the PGs involved, which do not act via the same signalling pathways. Indeed, PTGS2 is known to downregulate NF- $\kappa \mathrm{B}$-mediated transcription, whereas PGE2 activates this same transcription factor.

Another potent PG exerting antiviral activities, 15d$\mathrm{PGJ}_{2}$, inhibits transcriptional activation of HIV LTR by antagonizing NF- $\kappa \mathrm{B}$ in colonic epithelial cells through a PPAR- $\gamma$-independent mechanism [101]. It has been recently observed in human macrophages that $15 \mathrm{~d}-\mathrm{PGJ}_{2}$ can also modify free thiols in the viral transactivating Tat protein, thus suppressing its transactivation function [102]. Altogether, certain PGs can now be considered as anti-HIV eicosanoids and may very well contribute to the limitation of the systemic viral load in HIV-infected individuals.

\section{LTs and HIV}

Several studies have already shown how endogenous LTs play a critical role in the innate immune defence against bacterial and viral infections [103-107]. Regarding the response to HIV, most of our knowledge concerns $\mathrm{LTB}_{4}$. As early as 1989 , Thorsen and colleagues noticed that neutrophils isolated from patients infected with HIV display a reduced capacity of producing $\mathrm{LTB}_{4}$ [108]. Another group later demonstrated that, in HIVinfected subjects, a defect could be observed in the 5-
LO metabolic capacity of lung alveolar macrophages, which are resident cells primarily responsible for maintaining the sterility in the lungs. This diminished 5-LO efficiency was associated with a decreased expression of both 5-LO and FLAP in HIV-infected patients displaying low CD4 T-cell counts $\left(<200 / \mathrm{mm}^{3}\right)$ [109]. The same tendencies were observed in polymorphonuclear cells (PMNs) from subjects with low CD4 T-cell counts [110]. This decrease of LT synthesis capacity in alveolar macrophages and PMNs may negatively modulate the innate immune response to challenges by pathogens and opportunistic infections in the lungs during the late phase of HIV infection. For example, 5-LO knockout (KO) mice have a reduced survival rate after being inoculated intratracheally with K. pneumoniae, as compared to wild-type mice [111].

Recently, the existence of several 5-LO isoforms has been discovered in different human cell types (i.e. monocytes, B cells and PMNs). All cells examined express the full-length mRNA. On the other hand, the alternative forms of 5-LO appear to be expressed in a cell-type or cell-line specific manner. By themselves, these alternative isoforms are enzymatically inactive. Interestingly, the coexpression of these isoforms with the full-length 5-LO affects the capacity of cells to synthesize LTs [112]. How HIV infection can negatively modulate the LT production capacity of cells (i.e. alveolar macrophages and PMNs) remains to be explained. One may speculate that the 5-LO inefficacy brought about by HIV infection might be due to the upregulation of inactive 5-LO isoforms in cells, resulting in a downmodulation of their LT synthesis capacity. Additional studies are warranted to validate this hypothesis.

In general, LTs are considered to be mediators of antimicrobial host defence. In humans, administration of $\mathrm{LTB}_{4}$ to healthy individuals induces a plasmatic increase of $\alpha$-defensins and MIP-1 $\beta$, both well-known antiviral proteins. Interestingly, PMNs isolated from HIV-infected and non-infected subjects secrete similar amounts of $\alpha$ defensins in response to $\mathrm{LTB}_{4}$ activation [113], meaning that this LT can induce an antiviral response whether or not PMNs are exposed to HIV. Moreover, the secretome of PMNs obtained from healthy individuals treated with $\mathrm{LTB}_{4}$ contains several antimicrobial proteins including $\alpha$-defensins, cathepsin G, elastase, lysozyme C, and LL37 , which significantly attenuates infectivity of both X4and R5-tropic HIV variants [114].

\section{Non-steroidal anti-inflammatory drugs and HIV}

As they constitute COX inhibitors, it is relevant to discuss here the anti-HIV potential of non-steroidal antiinflammatory drugs (NSAIDs). In the HAART era, rheumatic manifestations have been reported to affect $9 \%$ of HIV-infected patients [115], and up to $60 \%$ of untreated 
individuals [116-118]. In such cases, NSAIDs are often the first line of medication prescribed. Indeed, many anti-inflammatory compounds (such as platelet-activating factor (PAF) receptor antagonist, aspirin and indomethacin) have demonstrated a certain anti-HIV potential. Interestingly, o-(acetoxyphenyl)hept-2-ynyl sulfide (APHS), an aspirin-derived molecule, has proven to be a compound with important anti-HIV properties. More precisely, APHS can act as a potent HIV inhibitor by negatively modulating Gag DNA synthesis during the reverse transcription (RT) process [119]. In addition, APHS can also act synergically with clinically available reverse transcriptase and protease inhibitors to inhibit several strains of HIV under in vitro conditions [120]. However, not all NSAIDs show anti-HIV properties. For instance, we have evaluated whether NS-398, another potent COX inhibitor [121], albeit specific for COX-2, could affect HIV replication in both MDMs and MDMi. We found that NS-398 does not significantly modulate HIV infection in these two distinct cellular models (unpublished data). This indicates that some mechanism other than the anti-COX-2 activities of APHS must be responsible for its anti-HIV potential. Interestingly, a recent clinical study has shown that celecoxib, another widely used COX-2 inhibitor, when administered to HIV-infected patients without antiretroviral treatment, downmodulates the immune activation related to clinical progression of chronic HIV infection and improves $\mathrm{T}$ cell-dependent functions in vivo. Indeed, a reduction in surface expression of CD38 and programmed death-1 is observed in cytotoxic $\mathrm{T}$ cells. Furthermore, the celecoxib treatment enhances the number of regulatory $\mathrm{T}$ cells and improves the humoral memory recall responses to a $\mathrm{T}$ cell-dependent vaccine [122]. Given the obvious beneficial potential of NSAIDs ability to modulate, either directly or indirectly, the replication cycle of HIV and the progressive immune dysfunctions occurring throughout the course of the disease, a better characterization of the mechanisms of action of these drugs is warranted.

\section{Eicosanoids present in the CNS}

Eicosanoids produced in the CNS play an important role in neuropathogenesis. Several different studies, mainly based on murine models, have shown that microglial cells produce many $\mathrm{COX}$ and 5-LO products, namely $\mathrm{PGE}_{2}, \mathrm{PGD}_{2}, \mathrm{LTB}_{4}, \mathrm{LTC}_{4}$, 5-HETE, 11-HETE and 15HETE [123-128]. Brain eicosanoids may also be secreted by cell types other than microglia, such as astrocytes, oligodendrocytes, neurons and endothelial cells, which play an important role in the propagation and maintenance of neuroinflammation $[129,130]$.

Not surprisingly, eicosanoid-producing enzymes COXs and lipoxygenases have also been detected in the CNS, either at the mRNA or protein level (Table 1). These enzymes are known to be stimulated during neuroinflammation [131]. For example, 5-LO is expressed in the CNS and has been known to be present in neurons, microglia and astrocyte cells [126,132-136]. As for COX-2, it is induced in most cells of the CNS, including neurons, microglia, astrocytes and oligodendrocytes [128,137-139]. Furthermore, microarray analysis has revealed that activation of mixed glial cells (predominately microglia) leads to striking increases in the expression of FLAP, 5-LO, 15-LO, COX-2, and PLA ${ }_{2}$, which are all HAD-associated gene products involved in LT or PG synthesis [27]. Moreover, a COX-1 splice variant, termed COX-3 or COX-1b, has also been detected at both the mRNA and protein levels in human brain tissues [140]. It has been shown to catalyze the synthesis of $\mathrm{PGF}_{2 \square}$, although less efficiently than COX-1.

Different prostanoid receptors, such as EP1-4 (receptor for $\mathrm{PGE}_{2}$ ), DP1-2 (receptor for $\mathrm{PGD}_{2}$ ), FP (receptor for $\mathrm{PGF}_{2 \alpha}$ ), and IP (receptor for $\mathrm{PGI}_{2}$ ), are found in the CNS, and their level of expression is often linked to the severity of cognitive impairment $[128,141,142]$ (Table 1). Meanwhile, the main LT receptors expressed in the human and murine CNS, more specifically by neurons,

Table 1 Summary table of the different receptors and eicosanoid-producing enzymes known to be found in the CNS and discussed in this review.

\begin{tabular}{|c|c|c|}
\hline Cells & Receptors & Enzymes \\
\hline \multirow[t]{5}{*}{ Microglia } & cysLT1 ${ }^{131}$ & $\operatorname{COX}-2^{123,127,135,138}$ \\
\hline & cysLT2 ${ }^{124}$ & 5-LO 124, 125, 132 \\
\hline & EP4 ${ }^{141}$ & FLAP 132 \\
\hline & EP2 ${ }^{141}$ & COX-1 128, 135, 137 \\
\hline & & PLA2 27 \\
\hline \multirow[t]{4}{*}{ Astrocytes } & EP2 ${ }^{141}$ & $5-\mathrm{LO}^{133}$ \\
\hline & & $\operatorname{cox}-2^{138}$ \\
\hline & & PLA2 ${ }^{129}$ \\
\hline & & $12-\mathrm{LO}^{130}$ \\
\hline \multirow[t]{2}{*}{ Oligodendrocytes } & GPR17 ${ }^{145}$ & $\operatorname{cox}-2^{138}$ \\
\hline & & $12-\mathrm{LO}{ }^{130}$ \\
\hline \multirow[t]{7}{*}{ Neurons } & BLT1 ${ }^{131}$ & 5-LO 133,135 \\
\hline & GPR17 89, 145 & $\operatorname{COX}-2^{128,} 134$ \\
\hline & cysLT2 ${ }^{144}$ & $12-\mathrm{LO}^{130}$ \\
\hline & EP2 ${ }^{141}$ & \\
\hline & EP1 ${ }^{141}$ & \\
\hline & EP3 ${ }^{141}$ & \\
\hline & EP4 ${ }^{141}$ & \\
\hline \multirow[t]{2}{*}{ Endothelial cells } & cysLT2 $^{147}$ & \\
\hline & EP4 ${ }^{141}$ & \\
\hline Unspecified & DP1-2 128 & \\
\hline \multirow[t]{2}{*}{ CNS cell types } & $\mathrm{FP}^{128}$ & \\
\hline & $\mathbb{P}^{128}$ & \\
\hline
\end{tabular}


endothelial and glial cells, are cysLT receptors, mostly cysLT2 and GPR17 [89,143-148].

The eicosanoids present in the CNS, whether or not they are produced by microglia, contribute greatly to neuroinflammation and HAD, as proinflammatory lipid mediators. In fact, the expression profile of 5-LO and COX products and of their receptors might serve as biomarkers for detecting CNS pathologies and their degree of severity.

\section{Interactions between HIV and eicosanoids in the CNS}

It is well known that elevated amounts of eicosanoids can be found in the brain and CSF of HIV-infected individuals $[142,149]$. Likewise, an upregulation of COX-2 expression is observed in in vitro cocultures of HIVinfected macrophages and brain endothelial cells, as well as in brain-derived cell lines exposed to soluble viral proteins [150-152]. We are, however, only starting to understand how eicosanoids interact with HIV. This section will focus on the complex direct or indirect interactions between HIV and COX-2, 5-LO and their products in the CNS, and on how this interplay might influence the progression of HIV-associated neurological impairments (Table 2).

\section{Relationship between HIV and COX- 2 and its products}

Although it is widely accepted that neurons do not support productive infection with HIV, there is clear evidence of neuronal loss in brains of HIV-infected individuals $[44,153,154]$. The viral surface glycoprotein gp120 is known to be greatly responsible for inducing neuroinflammation and neurodegeneration [155-158]. Interestingly, in vitro and in vivo studies have shown that enhanced COX-2 expression and $\mathrm{PGE}_{2}$ synthesis are involved in apoptosis observed in the CNS of rats following intracerebroventricular injection of gp120 [159-161]. Moreover, the varying degree of severity of neuroinflammation brought about by gp120 from different HIV clades is notably linked to the level of synthesis of certain COX products. Indeed, a recent study has indicated that human primary astrocytes exposed to purified gp120 from HIV clade B produce higher levels of COX-2 than astrocytes exposed to gp120 from clade $C$ [162]. However, the mechanisms through which gp120 induces COX-2 expression in the brain are still not fully understood. In vitro and in vivo data have revealed a role for IL-1 $\beta$ in mediating neurotoxicity induced by gp120 [163,164]. It has been shown that HIV gp120 can induce COX-2 expression not only in neuroblastoma cells, but also in astrocytoma cells through an NF- $\kappa \mathrm{B}$-mediated signal transduction pathway $[151,152]$. Furthermore, a recent study shows that the capacity of gp120 to induce COX-2 and its products in microglial cells greatly depends on the presence of IFN $_{\gamma}$ [7]. These data suggest that the IL- $1 \beta$ and IFN $_{\gamma^{-}}$ mediated COX-2 expression and $\mathrm{PGE}_{2}$ synthesis triggered by HIV gp120 in the CNS may account for the observed neuronal dysfunction. Thus, gp120 may be considered as a viral factor that potently induces neuroinflammation via COX-2 by interacting directly with cells of the CNS.

Another viral protein known to be released in the surrounding environment following HIV infection is Tat. It has been shown that both Tat and COX-2 are involved in the neuropathogenesis associated with HIV infection. For example, the upregulated expression of COX-2 in the $\mathrm{BBB}$ endothelial cells and macrophages brought on by HIV infection has been attributed, at least partly, to Tat-induced alterations of occludin expression, leading to the loss of tight junction integrity and the BBB breakdown $[150,165]$. Furthermore, an increase in COX-2 expression and $\mathrm{PGE}_{2}$ production is observed in astrocytoma cell lines and primary human astrocytes treated with Tat [166]. The intrahippocampal injection of Tat in mice induces a COX-2 expression not only in astrocytes, but also in microglial cells. Moreover, the proinflammatory effect of Tat is significantly attenuated upon treatment with the COX-2 inhibitor NS-398, which demonstrates the involvement of COX-2 in the Tat-

Table 2 Summary table of the known relationships between eicosanoids and HIV in the CNS.

\begin{tabular}{|c|c|c|c|c|c|c|}
\hline Exposure to & Type of cells or mode of exposure & Species & Product & Effect & Mediated by & Citation \\
\hline gp120 & intracerebral injection & rat & PGE2 & neuronal apoptosis & $\mathrm{IL}-1 \beta$ & 159,160 \\
\hline gp120 & intracerebral injection & rat & PGE2 & neuronal apoptosis & $N / A$ & 161 \\
\hline gp120 & astrocytes & human & PGE2 & neurotoxicity & $N / A$ & 162 \\
\hline gp120 & neurons & human & $N / A$ & neurotoxicity & 5-LO/PGHS & 172 \\
\hline Tat & intracerebral injection & mouse & $\mathrm{COX}-2$ & Neuroinflammation & $\mathrm{NFKb}$ & 166 \\
\hline Tat & tail vein injection & mouse & COX-2 & BBB disruption & $N / A$ & 165 \\
\hline LTs & microglia & human & $N / A$ & HIV inhibition & PKC & unpublished \\
\hline HIV-1 & endothelial cells/macrophages & human & $\operatorname{cox}-2$ & Neuroinflammation & $I L-1 b$ & 150 \\
\hline
\end{tabular}

N/A: Non available data

PGHS: prostaglandin $\mathrm{H}$ synthase 
induced neuropathogenesis [167]. Hence, exposure of astrocytes and microglia to either fully competent HIV particles or viral proteins promotes secretion of several proinflammatory molecules, including eicosanoid products, which greatly influences neuroinflammation and contributes to the severity of HIV-associated neurocognitive complications. This may be further explained by recent findings indicating that coculture with HIVinfected astrocytes is sufficient to increase the production of neurotoxic molecules released by virus-infected microglia such as PPP4R2, HSPA9 and NAP1L1 (proteins that regulate neuronal apoptosis) [61]. Although the role of COX-2 in brain inflammation is still not fully recognized, one may speculate that neurological complications that occur throughout the course of HIV infection may be in part mediated by COX-2 and its products. Another point to consider concerning HIVinfected patients is the potential effect of antiretrovirals on eicosanoids. For instance, maraviroc, a widely used CCR5 antagonist, is known to induce PG synthesis in microglia, thus strengthening their proinflammatory activation, which is likely to exacerbate neurological complications [7].

\section{Relationship between HIV and LTs}

Although previous studies have produced evidence of the anti-microbial properties of LTs, only recently have we established the relationship between LTs and viral infections in the CNS. For example, Chen and colleagues have shown that, during early infection with vesicular stomatitis virus, mice treated with the 5-LO antagonist Zileuton and 5-LO knock-out mice both presented an impaired infiltration process of neutrophils into the CNS, as well as fewer neurons expressing nitric oxide synthase-1, higher viral titres and increased disruption of the BBB [104]. These data clearly showed the protective role of LTs during viral infections in the CNS.

We now know that LTs are present in the CNS of HIV-infected individuals, where they can be produced by different cell types, including monocytes and microglia $[125,126,149,168]$. Moreover, recent studies have shown that high concentrations of eicosanoids, including $\mathrm{LTB}_{4}$, and several other AA cascade markers are found in the brain of HIV-transgenic rats $[169,170]$. In fact, cocultures of astroglial cells and HIV-infected monocytes release high levels of AA-derived metabolites, such as $\mathrm{LTB}_{4}$ and $\mathrm{LTD}_{4}$ [171], which can lead to neuroinflammation and neurotoxicity. Furthermore, gp120 induces necrotic death of human neuroblastoma cells by activating 5-LO [172]. This issue is, however, not without controversy since it has been shown that expression and activity of 5-LO can actually decrease in the rat neocortex upon the intracerebroventricular injection of gp120 [161]. The vast differences between the microenvironment of neuronal cells found in the rat brain neocortex upon gp120 intrathecal injection and the one studied in an in vitro experimental setup consisting of a single human cell type may account for the observed opposite effects of gp120 on 5-LO regulation.

Interestingly, our laboratory has shown that $\mathrm{LTB}_{4}$ and $\mathrm{LTC}_{4}$ negatively modulate HIV infection in MDMi's in a protein kinase $\mathrm{C}$-dependent manner (unpublished observations). This phenomenon may be explained in part by the fact that LTs inhibit the $\mathrm{pH}$-independent fusion step of the infection by decreasing the levels of CCR 5 on the cell surface. Moreover, decreased amounts of proviral DNA are found in LT-treated MDMi's, while RT products remain unaffected by LTs, indicating a blockage between the RT and integration steps of the infection.

Although LTs present in the CNS may exert an antiHIV effect, it is possible that HIV can counteract this phenomenon by inhibiting their production. On the other hand, a neurotoxic response induced by HIV infection in the CNS can also be mediated through 5LO products. The balance between the anti-HIV effect of LTs and their neuroinflammatory/neurotoxic effect might be pivotal in the development of neuroAIDS. Further research will be needed to better define the role played by LTs in the neuropathogenesis associated with HIV infection.

\section{Conclusion}

In summary, HIV-associated neurological impairments continue to be an important issue in the HAART era. We have learned that HIV-induced inflammation in the CNS, caused primarily by microglia and astrocytes, is greatly responsible for the neurological symptoms observed in virus-infected individuals. Importantly, multiple markers of brain AA metabolism are upregulated in the HIV-infected CNS, which may be correlated with dementia severity and behavioural deficits. The direct role of these potent inflammatory lipid mediators in the development and progression of the disease is still unfortunately poorly understood. Recent advances in the field have shown that COX and 5-LO products can negatively modulate HIV infection in different host cells. Therefore, PGs and LTs produced by innate immune cells may have an important role in controlling HIV replication, maybe more specifically in the CNS. This may explain, at least partially, how the viral load is often maintained at lower titres in this compartment than in the peripheral blood; the degree of penetration of antiretroviral agents in the CNS and their efficacy in the brain tissue also remain, of course, to be fully investigated.

We should examine more closely eicosanoid products in the CNS of infected individuals in the perspective of their ability to control the viral burden in this compartment, even though they are often associated with 
neuroinflammatory complications. In other regards, it would be worth evaluating the usefulness of eicosanoids as biomarkers to assess the severity of HIV-induced neurological impairments.

\author{
Author details \\ ${ }^{1}$ Centre de Recherche en Infectiologie, Centre Hospitalier Universitaire de \\ Québec - CHUL, 2705 boul. Laurier, Québec (QC), Canada, G1V 4G2. \\ ${ }^{2}$ Département de Microbiologie-Infectiologie et Immunologie, Faculté de \\ médecine, Université Laval, Québec, Canada.
}

\section{Authors' contributions}

JB carried out most of the literature research and the first draft. SM participated in the drafting and research of the literature. CB and MJT carefully reviewed the manuscript. All authors read and approved the final manuscript.

\section{Competing interests}

The authors declare that they have no competing interests.

Received: 26 October 2011 Accepted: 11 January 2012

Published: 11 January 2012

\section{References}

1. Davis LE, Hjelle BL, Miller VE, Palmer DL, Llewellyn AL, Merlin TL, Young SA, Mills RG, Wachsman W, Wiley CA: Early viral brain invasion in iatrogenic human immunodeficiency virus infection. Neurology 1992, 42:1736-1739.

2. Kraft-Terry SD, Stothert AR, Buch S, Gendelman HE: HIV-1 neuroimmunity in the era of antiretroviral therapy. Neurobiol Dis 2010, 37:542-548.

3. Antinori A, Arendt G, Becker JT, Brew BJ, Byrd DA, Cherner M, Clifford DB, Cinque P, Epstein LG, Goodkin K, Gisslen M, Grant I, Heaton RK, Joseph J, Marder K, Marra CM, McArthur JC, Nunn M, Price RW, Pulliam L, Robertson KR, Sacktor N, Valcour V, Wojna VE: Updated research nosology for HIV-associated neurocognitive disorders. Neurology 2007, 69:1789-1799.

4. Evers S, Rahmann A, Schwaag S, Frese A, Reichelt D, Husstedt IW: Prevention of AIDS dementia by HAART does not depend on cerebrospinal fluid drug penetrance. AIDS Res Hum Retroviruses 2004 20:483-491.

5. Wright E: Neurocognitive impairment and neuroCART. Curr Opin HIV AIDS 2011, 6:303-308

6. Ciccarelli N, Fabbiani M, Di Giambenedetto S, Fanti I, Baldonero E, Bracciale L, Tamburrini E, Cauda R, De Luca A, Silveri MC: Efavirenz associated with cognitive disorders in otherwise asymptomatic HIVinfected patients. Neurology 2011, 76:1403-1409.

7. Lisi L, Tramutola A, De Luca A, Navarra P, Dello Russo C: Modulatory effects of the CCR5 antagonist maraviroc on microglial pro-inflammatory activation elicited by gp120. J Neurochem 2011, 120:106-114.

8. Canestri A, Lescure FX, Jaureguiberry S, Moulignier A, Amiel C, Marcelin AG, Peytavin G, Tubiana R, Pialoux G, Katlama C: Discordance between cerebral spinal fluid and plasma HIV replication in patients with neurological symptoms who are receiving suppressive antiretroviral therapy. Clin Infect Dis 2010, 50:773-778.

9. Christo PP, Greco DB, Aleixo AW, Livramento JA: HIV-1 RNA levels in cerebrospinal fluid and plasma and their correlation with opportunistic neurological diseases in a Brazilian AIDS reference hospital. Arq Neuropsiquiatr 2005, 63:907-913.

10. De Luca A, Ciancio BC, Larussa D, Murri R, Cingolani A, Rizzo MG, Giancola ML, Ammassari A, Ortona L: Correlates of independent HIV-1 replication in the CNS and of its control by antiretrovirals. Neurology 2002, 59:342-347.

11. Price RW, Spudich S: Antiretroviral therapy and central nervous system HIV type 1 infection. J Infect Dis 2008, 197(Suppl 3):S294-306.

12. Gisslen M, Fuchs D, Svennerholm B, Hagberg L: Cerebrospinal fluid viral load, intrathecal immunoactivation, and cerebrospinal fluid monocytic cell count in HIV-1 infection. J Acquir Immune Defic Syndr 1999, 21:271-276.

13. Gisslen M, Svennerholm B, Norkrans G, Franzen C, Sall C, Svensson R, Oberg S, Hagberg L: Cerebrospinal fluid and plasma viral load in HIV-1- infected patients with various anti-retroviral treatment regimens. Scand J Infect Dis 2000, 32:365-369.

14. Schnell G, Spudich S, Harrington P, Price RW, Swanstrom R: Compartmentalized human immunodeficiency virus type 1 originates from long-lived cells in some subjects with HIV-1-associated dementia. PLOS Pathog 2009, 5:e1000395.

15. Witwer KW, Gama L, Li M, Bartizal CM, Queen SE, Varrone JJ, Brice AK, Graham DR, Tarwater PM, Mankowski JL, Zink MC, Clements JE: Coordinated regulation of SIV replication and immune responses in the CNS. PLoS One 2009, 4:e8129.

16. Barber SA, Herbst DS, Bullock BT, Gama L, Clements JE: Innate immune responses and control of acute simian immunodeficiency virus replication in the central nervous system. J Neurovirol 2004, 10(Suppl 1):15-20.

17. Hult B, Chana G, Masliah E, Everall I: Neurobiology of HIV. Int Rev Psychiatry 2008, 20:3-13.

18. Ivey NS, MacLean AG, Lackner AA: Acquired immunodeficiency syndrome and the blood-brain barrier. J Neurovirol 2009, 15:111-122.

19. Yadav A, Collman RG: CNS inflammation and macrophage/microglial biology associated with HIV-1 infection. J Neuroimmune Pharmacol 2009, 4:430-447.

20. Gonzalez-Scarano F, Martin-Garcia J: The neuropathogenesis of AIDS. Nat Rev Immunol 2005, 5:69-81.

21. Wu DT, Woodman SE, Weiss JM, McManus CM, D'Aversa TG, Hesselgesser J, Major EO, Nath A, Berman JW: Mechanisms of leukocyte trafficking into the CNS. J Neurovirol 2000, 6(Suppl 1):S82-85.

22. Dohgu S, Banks WA: Lipopolysaccharide-enhanced transcellular transport of HIV-1 across the blood-brain barrier is mediated by the p38 mitogenactivated protein kinase pathway. Exp Neurol 2008, 210:740-749.

23. Wang $H$, Sun J, Goldstein H: Human immunodeficiency virus type 1 infection increases the in vivo capacity of peripheral monocytes to cross the blood-brain barrier into the brain and the in vivo sensitivity of the blood-brain barrier to disruption by lipopolysaccharide. J Virol 2008, 82:7591-7600.

24. Ancuta P, Kamat A, Kunstman KJ, Kim EY, Autissier P, Wurcel A, Zaman T, Stone D, Mefford M, Morgello S, Singer EJ, Wolinsky SM, Gabuzda D: Microbial translocation is associated with increased monocyte activation and dementia in AIDS patients. PLoS One 2008, 3:e2516.

25. Strazza M, Pirrone V, Wigdahl B, Nonnemacher MR: Breaking down the barrier: the effects of HIV-1 on the blood-brain barrier. Brain Res 2011, 1399:96-115.

26. Alexaki A, Liu Y, Wigdahl B: Cellular reservoirs of HIV-1 and their role in viral persistence. Curr HIV Res 2008, 6:388-400.

27. Albright AV, Gonzalez-Scarano F: Microarray analysis of activated mixed glial (microglia) and monocyte-derived macrophage gene expression. $J$ Neuroimmunol 2004, 157:27-38.

28. Coisne C, Engelhardt B: Tight junctions in brain barriers during central nervous system inflammation. Antioxid Redox Signal 2011, 15:1285-1303.

29. Chan WY, Kohsaka S, Rezaie P: The origin and cell lineage of microglia: new concepts. Brain Res Rev 2007, 53:344-354.

30. Kaur C, Hao AJ, Wu CH, Ling EA: Origin of microglia. Microsc Res Tech 2001, 54:2-9.

31. Monier A, Adle-Biassette H, Delezoide AL, Evrard P, Gressens P, Verney C: Entry and distribution of microglial cells in human embryonic and fetal cerebral cortex. J Neuropathol Exp Neurol 2007, 66:372-382.

32. Cuadros MA, Navascues J: The origin and differentiation of microglial cells during development. Prog Neurobiol 1998, 56:173-189.

33. Davoust N, Vuaillat C, Androdias G, Nataf S: From bone marrow to microglia: barriers and avenues. Trends Immunol 2008, 29:227-234.

34. Buckner CM, Calderon TM, Willams DW, Belbin TJ, Berman JW: Characterization of monocyte maturation/differentiation that facilitates their transmigration across the blood-brain barrier and infection by HIV: implications for NeuroAIDS. Cell Immunol 2011, 267:109-123.

35. McManus CM, Brosnan CF, Berman JW: Cytokine induction of MIP-1 alpha and MIP-1 beta in human fetal microglia. J Immunol 1998, 160:1449-1455.

36. Matsumoto $Y$, Ohmori K, Fujiwara M: Microglial and astroglial reactions to inflammatory lesions of experimental autoimmune encephalomyelitis in the rat central nervous system. J Neuroimmunol 1992, 37:23-33.

37. Matsumoto $Y$, Ohmori K, Fujiwara M: Immune regulation by brain cells in the central nervous system: microglia but not astrocytes present myelin 
basic protein to encephalitogenic T cells under in vivo-mimicking conditions. Immunology 1992, 76:209-216.

38. Bauer J, Sminia T, Wouterlood FG, Dijkstra CD: Phagocytic activity of macrophages and microglial cells during the course of acute and chronic relapsing experimental autoimmune encephalomyelitis. $J$ Neurosci Res 1994, 38:365-375.

39. Lee SC, Liu W, Dickson DW, Brosnan CF, Berman JW: Cytokine production by human fetal microglia and astrocytes. Differential induction by lipopolysaccharide and IL-1 beta. J Immunol 1993, 150:2659-2667.

40. Gorry PR, Bristol G, Zack JA, Ritola K, Swanstrom R, Birch CJ, Bell JE, Bannert N, Crawford K, Wang H, Schols D, De Clercq E, Kunstman K. Wolinsky SM, Gabuzda D: Macrophage tropism of human immunodeficiency virus type 1 isolates from brain and lymphoid tissues predicts neurotropism independent of coreceptor specificity. J Virol 2001, 75:10073-10089.

41. Albright AV, Shieh JT, Itoh T, Lee B, Pleasure D, O'Connor MJ, Doms RW, Gonzalez-Scarano F: Microglia express CCR5, CXCR4, and CCR3, but of these, CCR5 is the principal coreceptor for human immunodeficiency virus type 1 dementia isolates. J Virol 1999, 73:205-213.

42. Agrawal L, Maxwell CR, Peters PJ, Clapham PR, Liu SM, Mackay CR, Strayer DS: Complexity in human immunodeficiency virus type 1 (HIV-1) co-receptor usage: roles of CCR3 and CCR5 in HIV-1 infection of monocyte-derived macrophages and brain microglia. J Gen Virol 2009, 90:710-722.

43. Aasa-Chapman MM, Aubin K, Williams I, McKnight A: Primary CCR5 only using HIV-1 isolates does not accurately represent the in vivo replicating quasi-species. Virology 2006, 351:489-496.

44. Adle-Biassette H, Chretien F, Wingertsmann L, Hery C, Ereau T, Scaravilli F, Tardieu M, Gray F: Neuronal apoptosis does not correlate with dementia in HIV infection but is related to microglial activation and axonal damage. Neuropathol App/ Neurobiol 1999, 25:123-133.

45. Jones MV, Bell JE, Nath A: Immunolocalization of HIV envelope gp120 in HIV encephalitis with dementia. Aids 2000, 14:2709-2713.

46. Viviani B, Corsini E, Binaglia M, Galli CL, Marinovich M: Reactive oxygen species generated by glia are responsible for neuron death induced by human immunodeficiency virus-glycoprotein 120 in vitro. Neuroscience 2001, 107:51-58.

47. Corasaniti MT, Bagetta G, Rotiroti D, Nistico G: The HIV envelope protein gp120 in the nervous system: interactions with nitric oxide, interleukin1 beta and nerve growth factor signalling, with pathological implications in vivo and in vitro. Biochem Pharmacol 1998, 56:153-156.

48. Hudson L, Liu J, Nath A, Jones M, Raghavan R, Narayan O, Male D, Everall I: Detection of the human immunodeficiency virus regulatory protein tat in CNS tissues. J Neurovirol 2000, 6:145-155.

49. Leone C, Le Pavec G, Meme W, Porcheray F, Samah B, Dormont D, Gras G Characterization of human monocyte-derived microglia-like cells. Glia 2006, 54:183-192.

50. Cherrier T, Suzanne S, Redel L, Calao M, Marban C, Samah B, Mukerjee R, Schwartz C, Gras G, Sawaya BE, Zeichner SL, Aunis D, Van Lint C, Rohr O p21(WAF1) gene promoter is epigenetically silenced by CTIP2 and SUV39H1. Oncogene 2009, 28:3380-3389.

51. Williams R, Bokhari S, Silverstein P, Pinson D, Kumar A, Buch S: Nonhuman primate models of NeuroAIDS. I Neurovirol 2008, 14:292-300.

52. Gorry PR, Ong C, Thorpe J, Bannwarth S, Thompson KA, Gatignol A, Vesselingh SL, Purcell DF: Astrocyte infection by HIV-1: mechanisms of restricted virus replication, and role in the pathogenesis of HIV-1associated dementia. Curr HIV Res 2003, 1:463-473.

53. Vijaykumar TS, Nath A, Chauhan A: Chloroquine mediated molecular tuning of astrocytes for enhanced permissiveness to HIV infection. Virology 2008, 381:1-5.

54. Canki M, Thai JN, Chao W, Ghorpade A, Potash MJ, Volsky DJ: Highly productive infection with pseudotyped human immunodeficiency virus type 1 (HIV-1) indicates no intracellular restrictions to HIV-1 replication in primary human astrocytes. J Virol 2001, 75:7925-7933.

55. Thompson KA, Cherry CL, Bell JE, McLean CA: Brain Cell Reservoirs of Latent Virus in Presymptomatic HIV-Infected Individuals. Am J Pathol 2011, 179:1623-1629.

56. Churchill MJ, Wesselingh SL, Cowley D, Pardo CA, MCArthur JC, Brew BJ, Gorry PR: Extensive astrocyte infection is prominent in human immunodeficiency virus-associated dementia. Ann Neurol 2009, 66:253-258.
57. Vincendeau M, Kramer S, Hadian K, Rothenaigner I, Bell J, Hauck SM Bickel C, Nagel D, Kremmer E, Werner T, Leib-Mösch C, Brack-Werner R: Control of HIV replication in astrocytes by a family of highly conserved host proteins with a common Rev-interacting domain (Risp). AIDS 2010, 24:2433-2442.

58. Wang Z, Trillo-Pazos G, Kim SY, Canki M, Morgello S, Sharer LR, Gelbard HA, Su ZZ, Kang DC, Brooks Al, Fisher PB, Volsky DJ: Effects of human immunodeficiency virus type 1 on astrocyte gene expression and function: potential role in neuropathogenesis. J Neurovirol 2004, 10(Suppl 1):25-32.

59. Kim SY, Li J, Bentsman G, Brooks Al, Volsky DJ: Microarray analysis of changes in cellular gene expression induced by productive infection of primary human astrocytes: implications for HAD. J Neuroimmunol 2004, 157:17-26.

60. Eugenin EA, Clements JE, Zink MC, Berman JW: Human immunodeficiency virus infection of human astrocytes disrupts blood-brain barrier integrity by a gap junction-dependent mechanism. J Neurosci 2011, 31:9456-9465.

61. Wang T, Gong N, Liu J, Kadiu I, Kraft-Terry SD, Schlautman JD, Ciborowski P, Volsky DJ, Gendelman HE: HIV-1-infected astrocytes and the microglial proteome. J Neuroimmune Pharmacol 2008, 3:173-186.

62. Radmark O, Samuelsson B: 5-Lipoxygenase: mechanisms of regulation. J Lipid Res 2009, 50(Suppl):S40-45.

63. Borgeat P, Hamberg M, Samuelsson B: Transformation of arachidonic acid and homo-gamma-linolenic acid by rabbit polymorphonuclear leukocytes. Monohydroxy acids from novel lipoxygenases. J Biol Chem 1976, 251:7816-7820.

64. Radmark O, Malmsten C, Samuelsson B: Leukotriene A4: enzymatic conversion to leukotriene C4. Biochem Biophys Res Commun 1980, 96:1679-1687.

65. Mitchell JA, Akarasereenont P, Thiemermann C, Flower RJ, Vane JR: Selectivity of nonsteroidal antiinflammatory drugs as inhibitors of constitutive and inducible cyclooxygenase. Proc Natl Acad Sci USA 1993, 90:11693-11697.

66. Seibert K, Masferrer JL: Role of inducible cyclooxygenase (COX-2) in inflammation. Receptor 1994, 4:17-23.

67. Botting R, Ayoub SS: COX-3 and the mechanism of action of paracetamol/acetaminophen. Prostaglandins Leukot Essent Fatty Acids 2005, 72:85-87.

68. Chandrasekharan NV, Dai H, Roos KL, Evanson NK, Tomsik J, Elton TS, Simmons DL: COX-3, a cyclooxygenase- 1 variant inhibited by acetaminophen and other analgesic/antipyretic drugs: cloning, structure, and expression. Proc Natl Acad Sci USA 2002, 99:13926-13931.

69. Chandrasekharan NV, Simmons DL: The cyclooxygenases. Genome Biol 2004, 5:241.

70. Funk CD: Prostaglandins and leukotrienes: advances in eicosanoid biology. Science 2001, 294:1871-1875.

71. Smith WL, DeWitt DL, Garavito RM: Cyclooxygenases: structural, cellular, and molecular biology. Annu Rev Biochem 2000, 69:145-182.

72. Cha Yl, Solnica-Krezel L, DuBois RN: Fishing for prostanoids: deciphering the developmental functions of cyclooxygenase-derived prostaglandins. Dev Biol 2006, 289:263-272.

73. Greenhough A, Smartt HJ, Moore AE, Roberts HR, Williams AC, Paraskeva C, Kaidi A: The COX-2/PGE2 pathway: key roles in the hallmarks of cancer and adaptation to the tumour microenvironment. Carcinogenesis 2009, 30:377-386.

74. Scher JU, Pillinger MH: The anti-inflammatory effects of prostaglandins. J Investig Med 2009, 57:703-708.

75. Surh YJ, Na HK, Park JM, Lee HN, Kim W, Yoon IS, Kim DD: 15-Deoxy-Delta $(12,14)$-prostaglandin $\mathrm{J}(2)$, an electrophilic lipid mediator of antiinflammatory and pro-resolving signaling. Biochem Pharmacol 2011, 82:1335-1351.

76. Samuelsson B: Leukotrienes: mediators of immediate hypersensitivity reactions and inflammation. Science 1983, 220:568-575.

77. Peters-Golden M, Henderson WR Jr: Leukotrienes. N Engl J Med 2007, 357:1841-1854

78. Peters-Golden M, Canetti C, Mancuso P, Coffey MJ: Leukotrienes: underappreciated mediators of innate immune responses. J Immunol 2005, 174:589-594

79. Borgeat P, Samuelsson B: Arachidonic acid metabolism in polymorphonuclear leukocytes: unstable intermediate in formation of dihydroxy acids. Proc Natl Acad Sci USA 1979, 76:3213-3217. 
80. Hopkins NK, Oglesby TD, Bundy GL, Gorman RR: Biosynthesis and metabolism of 15-hydroperoxy-5,8,11,13-eicosatetraenoic acid by human umbilical vein endothelial cells. J Biol Chem 1984, 259:14048-14053.

81. Humes $J$ L, Opas EE, Galavage M, Soderman D, Bonney RJ: Regulation of macrophage eicosanoid production by hydroperoxy-and hydroxyeicosatetraenoic acids. Biochem J 1986, 233:199-206.

82. Naruhn S, Meissner W, Adhikary T, Kaddatz K, Klein T, Watzer B, MullerBrusselbach S, Muller R: 15-hydroxyeicosatetraenoic acid is a preferential peroxisome proliferator-activated receptor beta/delta agonist. Mol Pharmacol 2010, 77:171-184.

83. Chen GG, Xu H, Lee JF, Subramaniam M, Leung KL, Wang SH, Chan UP, Spelsberg TC: 15-hydroxy-eicosatetraenoic acid arrests growth of colorectal cancer cells via a peroxisome proliferator-activated receptor gamma-dependent pathway. Int J Cancer 2003, 107:837-843.

84. Paruchuri S, Hallberg B, Juhas M, Larsson C, Sjolander A: Leukotriene D(4) activates MAPK through a Ras-independent but PKCepsilon-dependent pathway in intestinal epithelial cells. J Cell Sci 2002, 115:1883-1893.

85. Sanchez-Galan E, Gomez-Hernandez A, Vidal C, Martin-Ventura JL, BlancoColio LM, Munoz-Garcia B, Ortega L, Egido J, Tunon J: Leukotriene B4 enhances the activity of nuclear factor-kappaB pathway through BLT1 and BLT2 receptors in atherosclerosis. Cardiovasc Res 2009, 81:216-225.

86. Flamand N, Lefebvre J, Surette ME, Picard S, Borgeat P: Arachidonic acid regulates the translocation of 5-lipoxygenase to the nuclear membranes in human neutrophils. J Biol Chem 2006, 281:129-136.

87. Flamand N, Surette ME, Picard S, Bourgoin S, Borgeat P: Cyclic AMPmediated inhibition of 5-lipoxygenase translocation and leukotriene biosynthesis in human neutrophils. Mol Pharmacol 2002, 62:250-256.

88. Singh RK, Gupta S, Dastidar S, Ray A: Cysteinyl leukotrienes and their receptors: molecular and functional characteristics. Pharmacology 2010, 85:336-349.

89. Ciana $P$, Fumagalli $M$, Trincavelli ML, Verderio $C$, Rosa $P$, Lecca $D$, Ferrario $S$, Parravicini C, Capra V, Gelosa P, Guerrini U, Belcredito S, Cimino M, Sironi L, Tremoli E, Rovati GE, Martini C, Abbracchio MP: The orphan receptor GPR17 identified as a new dual uracil nucleotides/cysteinyl-leukotrienes receptor. Embo J 2006, 25:4615-4627.

90. Maekawa A, Balestrieri B, Austen KF, Kanaoka Y: GPR17 is a negative regulator of the cysteinyl leukotriene 1 receptor response to leukotriene D4. Proc Natl Acad Sci USA 2009, 106:11685-11690.

91. Breyer RM, Bagdassarian CK, Myers SA, Breyer MD: Prostanoid receptors: subtypes and signaling. Annu Rev Pharmacol Toxicol 2001, 41:661-690.

92. Scher JU, Pillinger $\mathrm{MH}: 15 \mathrm{~d}-\mathrm{PGJ}$ : the anti-inflammatory prostaglandin? Clin Immunol 2005, 114:100-109.

93. Yamamoto $\mathrm{N}$, Harada $\mathrm{S}$, Nakashima H: Substances affecting the infection and replication of human immunodeficiency virus (HIV). AIDS Res 1986, 2(Suppl 1):S183-189.

94. Ankel H, Turriziani O, Antonelli G: Prostaglandin A inhibits replication of human immunodeficiency virus during acute infection. J Gen Virol 1991 72(Pt 11):2797-2800

95. Hughes-Fulford M, McGrath MS, Hanks D, Erickson S, Pulliam L: Effects of dimethyl prostaglandin $\mathrm{A} 1$ on herpes simplex virus and human immunodeficiency virus replication. Antimicrob Agents Chemother 1992, 36:2253-2258

96. Rozera C, Carattoli A, De Marco A, Amici C, Giorgi C, Santoro MG: Inhibition of HIV-1 replication by cyclopentenone prostaglandins in acutely infected human cells. Evidence for a transcriptional block. J Clin Invest 1996, 97:1795-1803.

97. Thivierge M, Le Gouill C, Tremblay MJ, Stankova J, Rola-Pleszczynski M: Prostaglandin E2 induces resistance to human immunodeficiency virus-1 infection in monocyte-derived macrophages: downregulation of CCR5 expression by cyclic adenosine monophosphate. Blood 1998, 92:40-45

98. Hayes MM, Lane BR, King SR, Markovitz DM, Coffey MJ: Prostaglandin E(2) inhibits replication of HIV-1 in macrophages through activation of protein kinase A. Cell Immunol 2002, 215:61-71.

99. Whitney JB, Asmal M, Geiben-Lynn R: Serpin induced antiviral activity of prostaglandin synthetase-2 against HIV-1 replication. PLoS One 2011, 6: e18589.

100. Dumais N, Barbeau B, Olivier M, Tremblay MJ: Prostaglandin E2 Upregulates HIV-1 long terminal repeat-driven gene activity in T cells via NF-kappaB-dependent and -independent signaling pathways. J Biol Chem 1998, 273:27306-27314
101. Boisvert M, Cote S, Vargas A, Pasvanis S, Bounou S, Barbeau B, Dumais N: PGJ2 antagonizes NF-kappaB-induced HIV-1 LTR activation in colonic epithelial cells. Virology 2008, 380:1-11.

102. Kalantari P, Narayan V, Henderson AJ, Prabhu KS: 15-Deoxy-Delta12,14prostaglandin $\mathrm{J} 2$ inhibits HIV-1 transactivating protein, Tat, through covalent modification. Faseb J 2009, 23:2366-2373

103. Bailie MB, Standiford TJ, Laichalk LL, Coffey MJ, Strieter R, Peters-Golden M: Leukotriene-deficient mice manifest enhanced lethality from Klebsiella pneumonia in association with decreased alveolar macrophage phagocytic and bactericidal activities. J Immunol 1996, 157:5221-5224.

104. Chen N, Restivo A, Reiss CS: Leukotrienes play protective roles early during experimental VSV encephalitis. J Neuroimmunol 2001, 120:94-102.

105. Demitsu T, Katayama H, Saito-Taki T, Yaoita H, Nakano M: Enhanced bactericidal activity of macrophages by exogenous leukotriene B4. Dermatologica 1989, 179(Suppl 1):129-130

106. Malaviya R, Abraham SN: Role of mast cell leukotrienes in neutrophil recruitment and bacterial clearance in infectious peritonitis. J Leukoc Biol 2000, 67:841-846.

107. Medeiros Al, Sa-Nunes A, Soares EG, Peres CM, Silva CL, Faccioli LH: Blockade of endogenous leukotrienes exacerbates pulmonary histoplasmosis. Infect Immun 2004, 72:1637-1644.

108. Thorsen S, Busch-Sorensen M, Sondergaard J: Reduced neutrophil production of leukotriene B4 associated with AIDS. Aids 1989, 3:651-653

109. Coffey MJ, Phare SM, Kazanjian PH, Peters-Golden M: 5-Lipoxygenase metabolism in alveolar macrophages from subjects infected with the human immunodeficiency virus. J Immunol 1996, 157:393-399.

110. Coffey MJ, Phare SM, George S, Peters-Golden M, Kazanjian PH: Granulocyte colony-stimulating factor administration to HIV-infected subjects augments reduced leukotriene synthesis and anticryptococcal activity in neutrophils. J Clin Invest 1998, 102:663-670.

111. Peters-Golden M, Coffey M: Role of leukotrienes in antimicrobial defense of the lung. J Lab Clin Med 1998, 132:251-257.

112. Boudreau LH, Bertin J, Robichaud PP, Laflamme M, Ouellette RJ, Flamand N, Surette ME: Novel 5-lipoxygenase isoforms affect the biosynthesis of 5lipoxygenase products. Faseb J 2011, 25:1097-1105.

113. Flamand L, Borgeat $\mathrm{P}$, Lalonde R, Gosselin J: Release of anti-HIV mediators after administration of leukotriene B4 to humans. J Infect Dis 2004, 189:2001-2009.

114. Flamand L, Tremblay MJ, Borgeat P: Leukotriene B4 triggers the in vitro and in vivo release of potent antimicrobial agents. J Immunol 2007, 178:8036-8045.

115. Yao Q, Frank M, Glynn M, Altman RD: Rheumatic manifestations in HIV-1 infected in-patients and literature review. Clin Exp Rheumatol 2008, 26:799-806.

116. Cuellar ML: HIV infection-associated inflammatory musculoskeletal disorders. Rheum Dis Clin North Am 1998, 24:403-421.

117. Berman A, Espinoza LR, Diaz JD, Aguilar JL, Rolando T, Vasey FB, Germain BF, Lockey RF: Rheumatic manifestations of human immunodeficiency virus infection. Am J Med 1988, 85:59-64.

118. Calabrese LH, Kelley DM, Myers A, O'Connell M, Easley K: Rheumatic symptoms and human immunodeficiency virus infection. The influence of clinical and laboratory variables in a longitudinal cohort study. Arthritis Rheum 1991, 34:257-263.

119. Pereira CF, Paridaen JT, Rutten K, Huigen MC, van de Bovenkamp M Middel J, Beerens N, Berkhout B, Schuurman R, Marnett LJ, Verhoef J, Nottet HS: Aspirin-like molecules that inhibit human immunodeficiency virus 1 replication. Antiviral Res 2003, 58:253-263.

120. Pereira CF, Paridaen JT, van de Bovenkamp M, Middel J, Verhoef J, Nottet HS: APHS can act synergically with clinically available HIV-1 reverse transcriptase and protease inhibitors and is active against several drug-resistant HIV-1 strains in vitro. J Antimicrob Chemother 2003, 51:1181-1189.

121. Futaki N, Takahashi S, Yokoyama M, Arai I, Higuchi S, Otomo S: NS-398, a new anti-inflammatory agent, selectively inhibits prostaglandin $\mathrm{G} / \mathrm{H}$ synthase/cyclooxygenase (COX-2) activity in vitro. Prostaglandins 1994, 47:55-59.

122. Pettersen FO, Torheim EA, Dahm AE, Aaberge IS, Lind A, Holm M, Aandahl EM, Sandset PM, Tasken K, Kvale D: An exploratory trial of cyclooxygenase type 2 inhibitor in HIV-1 infection: downregulated immune activation and improved T cell-dependent vaccine responses. J Virol 2011, 85:6557-6566. 
123. Zhang D, Hu X, Qian L, Wilson B, Lee C, Flood P, Langenbach R, Hong JS: Prostaglandin E2 released from activated microglia enhances astrocyte proliferation in vitro. Toxicol Appl Pharmacol 2009, 238:64-70.

124. Rademacher DJ, Kearn CS, Carrier EJ, Patel S, Delgado MA, Barkmeier A, Klick DE, Breese NM, Pfister SL, Nithipatikom K, Campbell WB, Hillard CJ: Production of hydroxyeicosatetraenoic acids and prostaglandins by a novel rat microglial cell line. J Neuroimmunol 2004, 149:130-141.

125. Matsuo M, Hamasaki Y, Fujiyama F, Miyazaki S: Eicosanoids are produced by microglia, not by astrocytes, in rat glial cell cultures. Brain Res 1995 , 685:201-204

126. Ballerini P, Di lorio P, Ciccarelli R, Caciagli F, Poli A, Beraudi A, Buccella S, D'Alimonte I, D'Auro M, Nargi E, Patricelli P, Visini D, Traversa U: P2Y1 and cysteinyl leukotriene receptors mediate purine and cysteinyl leukotriene co-release in primary cultures of rat microglia. Int J Immunopathol Pharmacol 2005, 18:255-268.

127. Minghetti L, Ajmone-Cat MA, De Berardinis MA, De Simone R: Microglial activation in chronic neurodegenerative diseases: roles of apoptotic neurons and chronic stimulation. Brain Res Brain Res Rev 2005, 48:251-256.

128. Choi SH, Aid S, Bosetti F: The distinct roles of cyclooxygenase-1 and -2 in neuroinflammation: implications for translational research. Trends Pharmacol Sci 2009, 30:174-181.

129. Lin TN, Wang Q, Simonyi A, Chen JJ, Cheung WM, He YY, Xu J, Sun AY, Hsu CY, Sun GY: Induction of secretory phospholipase A2 in reactive astrocytes in response to transient focal cerebral ischemia in the rat brain. J Neurochem 2004, 90:637-645.

130. Bendani MK, Palluy O, Cook-Moreau J, Beneytout JL, Rigaud M, Vallat JM: Localization of 12-lipoxygenase mRNA in cultured oligodendrocytes and astrocytes by in situ reverse transcriptase and polymerase chain reaction. Neurosci Lett 1995, 189:159-162.

131. Farooqui AA, Horrocks LA, Farooqui T: Modulation of inflammation in brain: a matter of fat. J Neurochem 2007, 101:577-599.

132. Okubo M, Yamanaka H, Kobayashi K, Noguchi K: Leukotriene synthases and the receptors induced by peripheral nerve injury in the spinal cord contribute to the generation of neuropathic pain. Glia 2010, 58:599-610.

133. Jeon SB, Ji KA, You HJ, Kim JH, Jou I, Joe EH: Nordihydroguaiaretic acid inhibits IFN-gamma-induced STAT tyrosine phosphorylation in rat brain astrocytes. Biochem Biophys Res Commun 2005, 328:595-600.

134. Manev H, Uz T, Qu T: Early upregulation of hippocampal 5-lipoxygenase following systemic administration of kainate to rats. Restor Neurol Neurosci 1998, 12:81-85.

135. Tomimoto $H$, Shibata $M$, Ihara $M$, Akiguchi I, Ohtani R, Budka H: A comparative study on the expression of cyclooxygenase and 5 lipoxygenase during cerebral ischemia in humans. Acta Neuropathol 2002, 104:601-607.

136. Ohtsuki T, Matsumoto M, Hayashi Y, Yamamoto K, Kitagawa K, Ogawa S, Yamamoto S, Kamada T: Reperfusion induces 5-lipoxygenase translocation and leukotriene C4 production in ischemic brain. Am J Physiol 1995, 268:H1249-1257

137. Hoozemans JJ, Veerhuis R, Janssen I, van Elk EJ, Rozemuller AJ, Eikelenboom P: The role of cyclo-oxygenase 1 and 2 activity in prostaglandin $\mathrm{E}(2)$ secretion by cultured human adult microglia: implications for Alzheimer's disease. Brain Res 2002, 951:218-226.

138. Temel SG, Kahveci Z: Cyclooxygenase-2 expression in astrocytes and microglia in human oligodendroglioma and astrocytoma. J Mol Histol 2009, 40:369-377.

139. Carlson NG, Rojas MA, Redd JW, Tang P, Wood B, Hill KE, Rose JW: Cyclooxygenase-2 expression in oligodendrocytes increases sensitivity to excitotoxic death. J Neuroinflammation 2010, 7:25.

140. Qin N, Zhang SP, Reitz TL, Mei JM, Flores CM: Cloning, expression, and functional characterization of human cyclooxygenase-1 splicing variants: evidence for intron 1 retention. J Pharmacol Exp Ther 2005, 315:1298-1305.

141. Andreasson K: Emerging roles of PGE2 receptors in models of neurological disease. Prostaglandins Other Lipid Mediat 2010, 91:104-112.

142. Griffin DE, Wesselingh SL, McArthur JC: Elevated central nervous system prostaglandins in human immunodeficiency virus-associated dementia. Ann Neurol 1994, 35:592-597.

143. Heise CE, O'Dowd BF, Figueroa DJ, Sawyer N, Nguyen T, Im DS, Stocco R, Bellefeuille JN, Abramovitz M, Cheng R, Williams DL Jr, Zeng Z, Liu Q, Ma L, Clements MK, Coulombe N, Liu Y, Austin CP, George SR, O'Neill GP, Metters KM, Lynch KR, Evans JF: Characterization of the human cysteinyl leukotriene 2 receptor. J Biol Chem 2000, 275:30531-30536.
144. Hu H, Chen G, Zhang JM, Zhang WP, Zhang L, Ge QF, Yao HT, Ding W, Chen Z, Wei EQ: Distribution of cysteinyl leukotriene receptor 2 in human traumatic brain injury and brain tumors. Acta Pharmacol Sin 2005, 26:685-690.

145. Lecca D, Trincavelli ML, Gelosa P, Sironi L, Ciana P, Fumagalli M, Villa G, Verderio C, Grumelli C, Guerrini U, Tremoli E, Rosa P, Cuboni S, Martini C, Buffo A, Cimino M, Abbracchio MP: The recently identified P2Y-like receptor GPR17 is a sensor of brain damage and a new target for brain repair. PLoS One 2008, 3:e3579.

146. Hui Y, Funk CD: Cysteinyl leukotriene receptors. Biochem Pharmacol 2002, 64:1549-1557.

147. Di Gennaro A, Carnini C, Buccellati C, Ballerio R, Zarini S, Fumagalli F, Viappiani S, Librizzi L, Hernandez A, Murphy RC, Constantin G, De Curtis M, Folco G, Sala A: Cysteinyl-leukotrienes receptor activation in brain inflammatory reactions and cerebral edema formation: a role for transcellular biosynthesis of cysteinyl-leukotrienes. Faseb J 2004, 18:842-844.

148. Zhang WP, Hu H, Zhang L, Ding W, Yao HT, Chen KD, Sheng WW, Chen Z, Wei EQ: Expression of cysteinyl leukotriene receptor 1 in human traumatic brain injury and brain tumors. Neurosci Lett 2004, 363:247-251.

149. Froldi M, Castagna A, Parma M, Piona A, Tedeschi A, Miadonna A, Lorini M, Orazio EN, Lazzarin A: Mediator release in cerebrospinal fluid of human immunodeficiency virus-positive patients with central nervous system involvement. J Neuroimmunol 1992, 38:155-161.

150. Pereira CF, Boven LA, Middel J, Verhoef J, Nottet HS: Induction of cyclooxygenase-2 expression during HIV-1-infected monocyte-derived macrophage and human brain microvascular endothelial cell interactions. J Leukoc Biol 2000, 68:423-428.

151. Alvarez S, Serramia MJ, Fresno M, Munoz-Fernandez M: Human immunodeficiency virus type 1 envelope glycoprotein 120 induces cyclooxygenase-2 expression in neuroblastoma cells through a nuclear factor-kappaB and activating protein-1 mediated mechanism. J Neurochem 2005, 94:850-861.

152. Alvarez S, Serramia MJ, Fresno M, Munoz-Fernandez MA: HIV-1 envelope glycoprotein 120 induces cyclooxygenase-2 expression in astrocytoma cells through a nuclear factor-kappaB-dependent mechanism. Neuromolecular Med 2007, 9:179-193.

153. Gray F, Adle-Biassette H, Brion F, Ereau T, le Maner I, Levy V, Corcket G: Neuronal apoptosis in human immunodeficiency virus infection. J Neurovirol 2000, 6(Suppl 1):S38-43.

154. Gray F, Adle-Biassette H, Chretien F, Lorin de la Grandmaison G, Force G, Keohane C: Neuropathology and neurodegeneration in human immunodeficiency virus infection. Pathogenesis of HIV-induced lesions of the brain, correlations with HIV-associated disorders and modifications according to treatments. Clin Neuropathol 2001, 20:146-155.

155. Bansal AK, Mactutus CF, Nath A, Maragos W, Hauser KF, Booze RM: Neurotoxicity of HIV-1 proteins gp120 and Tat in the rat striatum. Brain Res 2000, 879:42-49.

156. Louboutin JP, Reyes BA, Agrawal L, Van Bockstaele EJ, Strayer DS: HIV-1 gp120-induced neuroinflammation: relationship to neuron loss and protection by rSV40-delivered antioxidant enzymes. Exp Neurol 2010, 221:231-245.

157. Kaul M, Lipton SA: Chemokines and activated macrophages in HIV gp120-induced neuronal apoptosis. Proc Natl Acad Sci USA 1999, 96:8212-8216.

158. Medders KE, Sejbuk NE, Maung R, Desai MK, Kaul M: Activation of p38 MAPK is required in monocytic and neuronal cells for HIV glycoprotein 120-induced neurotoxicity. J Immunol 2010, 185:4883-4895.

159. Corasaniti MT, Rotiroti D, Nappi G, Bagetta G: Neurobiological mediators of neuronal apoptosis in experimental neuroAIDS. Toxicol Lett 2003, 139:199-206.

160. Bagetta G, Corasaniti MT, Paoletti AM, Berliocchi L, Nistico R, Giammarioli AM, Malorni W, Finazzi-Agro A: HIV-1 gp120-induced apoptosis in the rat neocortex involves enhanced expression of cyclooxygenase type 2 (COX-2). Biochem Biophys Res Commun 1998, 244:819-824

161. Maccarrone M, Bari M, Corasaniti MT, Nistico R, Bagetta G, Finazzi-Agro A: HIV-1 coat glycoprotein gp120 induces apoptosis in rat brain neocortex by deranging the arachidonate cascade in favor of prostanoids. $J$ Neurochem 2000, 75:196-203. 
162. Samikkannu T, Agudelo M, Gandhi N, Reddy PV, Saiyed ZM, Nwankwo D, Nair MP: Human immunodeficiency virus type 1 clade B and C gp120 differentially induce neurotoxin arachidonic acid in human astrocytes: implications for neuroAIDS. J Neurovirol 2011, 17:230-238.

163. Corasaniti MT, Turano P, Bilotta A, Malorni W, Stringaro AR, Nistico R, Finazzi-Agro A, Bagetta G: Evidence that increases of mitochondrial immunoreactive IL-1beta by HIV-1 gp120 implicate in situ cleavage of pro-IL-1beta in the neocortex of rat. J Neurochem 2001, 78:611-618.

164. Corasaniti MT, Bilotta A, Strongoli MC, Navarra M, Bagetta G, Di Renzo G: HIV-1 coat protein gp120 stimulates interleukin-1beta secretion from human neuroblastoma cells: evidence for a role in the mechanism of cell death. Br J Pharmacol 2001, 134:1344-1350.

165. Pu H, Hayashi K, Andras IE, Eum SY, Hennig B, Toborek M: Limited role of COX-2 in HIV Tat-induced alterations of tight junction protein expression and disruption of the blood-brain barrier. Brain Res 2007, 1184:333-344.

166. Blanco A, Alvarez S, Fresno M, Munoz-Fernandez MA: Extracellular HIV-Tat induces cyclooxygenase-2 in glial cells through activation of nuclear factor of activated T cells. J Immunol 2008, 180:530-540.

167. Flora G, Pu H, Hennig B, Toborek M: Cyclooxygenase-2 is involved in HIV1 Tat-induced inflammatory responses in the brain. Neuromolecular Med 2006, 8:337-352.

168. Wahl LM, Corcoran ML, Pyle SW, Arthur LO, Harel-Bellan A, Farrar WL: Human immunodeficiency virus glycoprotein (gp120) induction of monocyte arachidonic acid metabolites and interleukin 1. Proc Natl Acad Sci USA 1989, 86:621-625

169. Basselin M, Ramadan E, Igarashi M, Chang L, Chen M, Kraft AD, Harry GJ, Rapoport SI: Imaging upregulated brain arachidonic acid metabolism in HIV-1 transgenic rats. J Cereb Blood Flow Metab 2011, 31:486-493.

170. Rao JS, Kim HW, Kellom M, Greenstein D, Chen M, Kraft AD, Harry GJ, Rapoport SI, Basselin M: Increased neuroinflammatory and arachidonic acid cascade markers, and reduced synaptic proteins, in brain of HIV-1 transgenic rats. J Neuroinflammation 2011, 8:101.

171. Genis P, Jett M, Bernton EW, Boyle T, Gelbard HA, Dzenko K, Keane RW, Resnick L, Mizrachi Y, Volsky DJ, Epstein LG, Gendelman HE: Cytokines and arachidonic metabolites produced during human immunodeficiency virus (HIV)-infected macrophage-astroglia interactions: implications for the neuropathogenesis of HIV disease. J Exp Med 1992, 176:1703-1718.

172. Maccarrone M, Navarra M, Corasaniti MT, Nistico G, Finazzi Agro A: Cytotoxic effect of HIV-1 coat glycoprotein gp120 on human neuroblastoma CHP100 cells involves activation of the arachidonate cascade. Biochem J 1998, 333(Pt 1):45-49.

173. Niknami M, Patel M, Witting PK, Dong Q: Molecules in focus: cytosolic phospholipase A2-alpha. Int J Biochem Cell Biol 2009, 41:994-997.

doi:10.1186/1742-4690-9-4

Cite this article as: Bertin et al:: Interactions between prostaglandins, leukotrienes and HIV-1: Possible implications for the central nervous system. Retrovirology 2012 9:4.

\section{Submit your next manuscript to BioMed Central and take full advantage of:}

- Convenient online submission

- Thorough peer review

- No space constraints or color figure charges

- Immediate publication on acceptance

- Inclusion in PubMed, CAS, Scopus and Google Scholar

- Research which is freely available for redistribution

Submit your manuscript at www.biomedcentral.com/submit
Biomed Central 